\title{
Use of Figurative Language by People With Parkinson Disease to Describe “Off” Periods
}

\section{Clear as Mud}

Lana M. Chahine, MD, MS, Briana Edison, MPH, Margaret Daeschler, MA, Bernadette Siddiqi, MA, Catherine Kopil, PhD, Connie Marras, MD, PhD, and Sneha Mantri, MD, MS

Neurology: Clinical Practice August 2021 vol. 11 no. 4 e462-e471 doi:10.1212/CPJ.0000000000001059

\author{
Correspondence \\ Dr. Chahine \\ Ichahine2018@gmail.com
}

\begin{abstract}
Objective

"Off" periods are characterized by the reemergence of motor and nonmotor symptoms in individuals with Parkinson disease (PD) and often negatively affect daily functioning. Individuals' experiences are diverse and may be difficult to articulate; figurative language is often used by patients to describe such experiences. Our objective was to understand how individuals with PD use figurative language to explain off periods and how experts interpret such expressions.
\end{abstract}

\section{Methods}

Individuals with self-reported PD participating in the online Fox

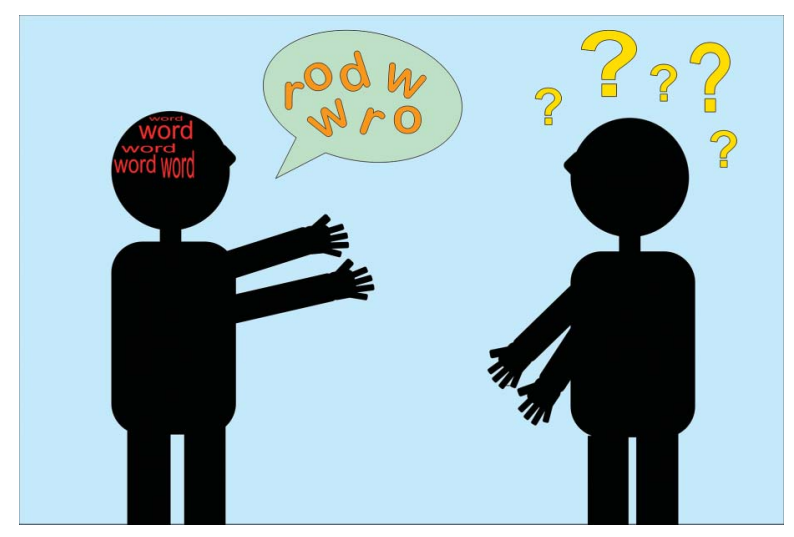
Insight study were invited to participate in a survey about off periods. Those endorsing off periods were asked to describe their experiences with open-ended free-text responses. Instances where any type of figurative language was used were identified and classified into themes. Three movement disorder neurologists reviewed each phrase and specified what symptoms they felt were likely represented.

\section{Results}

A total of 109 instances of figurative language phrases were identified across descriptions from 86 patients. Allusions to viscous materials (e.g., mud and cement) and effects of chemicals (e.g., drunkenness) were common ( $18.35 \%$ and $17.43 \%$ of phrases, respectively). Most phrases were interpreted by the neurologists as representing motor symptoms, but neurologists agreed on what specific symptom was being referred to for only 42 (38.5\%) phrases.

\section{Conclusions}

To describe off periods, individuals with PD use various forms of figurative language, but this language is not uniformly interpreted and understood by specialists. Given the subjective interpretation of figurative language, exploring what patients are trying to convey when they use such language is important and could improve patient-physician communication. 
Many individuals with Parkinson disease fluctuate between periods in which their symptoms are better controlled ["on" periods] and periods during which their symptoms return ["off" periods]. Experiences with off periods are diverse and may be difficult to articulate; figurative language may be used by patients to describe such experiences.

Successful exchange of information is a core tenet of patientphysician communication. Figurative language, such as metaphors and similes, involves the use of the nonliteral meaning of a word or phrase to convey information. Figurative language is commonly used in spontaneous speech, where it is often used to describe abstract, complex, or emotionally laden experiences. ${ }^{1-4}$ Consistent with the latter, patients with various life-threatening and/or chronic illnesses use figurative language in describing symptoms and experiences. ${ }^{4,5}$ For example, patients with cancer often use war or military metaphors. There are few data on the use of figurative language among individuals with neurologic disorders. In 1 study of individuals with motor neuron disease, expressions of entrapment and journeying through landscape were commonly used. ${ }^{6}$ Patients with Alzheimer disease and their caregivers liken the disease to a journey with no return. ${ }^{7}$ How the use of figurative language by a patient is understood and interpreted by their provider is not known but would be useful to explore toward narrative competency of physicians, ${ }^{8}$ and ultimately improving patient-physician communication and patient outcomes. ${ }^{8,9}$

We conducted a study to understand patient experiences with off periods in Parkinson disease (PD). ${ }^{10}$ Off periods are characterized by the reemergence of motor and nonmotor symptoms as the effect of dopaminergic therapy wears off. The occurrence of off periods has a significant negative impact on the quality of life (QOL). ${ }^{11}$ However, they remain underdetected $^{12}$ and thus possibly undertreated, perhaps in part because of their substantial heterogeneity, complex manifestations, and interindividual and even intraindividual variability in their expression. To improve understanding of how patients experience off periods and communicate about them, we undertook an in-depth analysis of how patients describe off periods. During this work, we identified several instances in which patients used figurative language. We present those findings here with 2 main objectives. First, to describe the types of figurative language used and the themes represented in them. Second, to explore how movement disorders experts interpret figurative language used by patients with $\mathrm{PD}$.

\section{Methods}

\section{Study Design, Sample, and Assessments}

This was a cross-sectional survey study. Details of the study design, sample, and assessments have been previously reported. ${ }^{10}$ Briefly, a questionnaire was deployed to individuals with self-reported PD participating in the online Fox Insight (FI) study. ${ }^{13}$ Inclusion criteria were residence in the United States and taking $\geq 1$ PD medications. On November 26, 2018, a survey invitation was sent to eligible participants $(n=13,359)$. Those who clicked on the survey were presented with the following question: "Many individuals with Parkinson disease fluctuate between periods in which their symptoms are better controlled and periods during which symptoms return. We refer to the periods during which symptoms are better controlled as on, and periods during which symptoms return as off. Based on this definition of off, do you experience off periods?" Those responding yes progressed to receive the study questionnaire as described. ${ }^{10}$

One of the questions stated: "In the space provided below please describe your experience when you are off." Openended, free-text, character-unlimited responses could be typed in by participants. Responses to this question are the subject of the analysis presented here. Two thousand six hundred eighty-four individuals clicked on the survey link; 49 did not fill out any part of survey, 15 did not endorse diagnosis of PD at their registration visit for FI, 3 had missing age, and 3 had age of PD onset as 0 (considered erroneous entry by the participant). Thus, responses to this question for 2,110 participants were included in this analysis. Each response was reviewed in detail by one of the authors (B.E.). During this review, responses that included any form of figurative language (such as metaphor, simile, or personification) were identified. Responses that included the use of medical terminology were also identified, including verbatim use of the terms bradykinesia, dyskinesia, dystonia, freezing of gait, micrographia, and akathisia, paresthesia(s), and orthostatic hypotension, or misspelled versions of these terms that are clearly identifiable (such as dyskenisia, dyskenisia, and dyskensia). Responses not using figurative language or medical terminology were considered literal descriptions.

\section{Qualitative Analysis and Interpretation of Figurative Language}

Each use of figurative language was reviewed, and a list of themes or categorizations common to at least 2 of the figurative language phrases was generated (by author B.E.). A neurologist and movement disorders specialist with advanced training in narrative medicine (author S.M.) then reviewed each figurative language phrase and classified it into one or more of the theme 
categories listed. The classifications were then reviewed by authors B.E., S.M., and L.M.C., and final categorizations were chosen after discussion. In the process, the original list of themes was refined to consolidate categories.

A goal of this analysis was to determine how a movement disorders specialist who encounters each of the figurative language phrases would interpret them. Specifically, what symptom or symptoms the movement disorders specialist believed the patient was referring to with the use of the figurative language.

Three neurologists who are movement disorders specialists (authors L.M.C., S.M., and C.M.) generated a list of common PD symptoms that, based on their expert opinion, could be reported to occur during off periods. Each neurologist then independently reviewed each instance of figurative language. To simulate how a phrase might be encountered in the clinical setting, the neurologist was presented the entire verbatim response as given by the participant, but the part of the response that included figurative language was highlighted. The neurologist classified the figurative language phrase as representing one or more symptoms from the prespecified list. Where necessary, the neurologist could add additional symptoms (not on the list). Finally, the neurologist was required to specify the one symptom they thought was most likely to be conveyed by the figurative language phrase. The neurologist had the option to specify "I don't know" but only as a last resort. The initial list of symptoms and symptoms added subsequent to review is shown in table 1. For analytic purposes, these symptoms were grouped according to general category (motor or nonmotor symptoms that fall under a general category of symptoms based on opinion of the authors).

\section{Statistical Analysis}

Descriptive statistics were used to summarize the study cohort characteristics. Two-sample $t$ test and $\chi^{2}$ test for homogeneity were used to compare characteristics of those using figurative language vs those who did not. Fleiss kappa was used to compare inter-rater agreement among the 3 neurologists for a given symptom category; inter-rater agreement was considered greater than expected by chance when $p<0.05$. Equality of proportions tests were used to compare, for each pair of symptom categories, the proportion of phrases for which agreement was present among all 3 neurologists on the most likely symptom represented by that phrase; significant difference in proportion was defined when $p<0.05$.

\section{Standard Protocol Approvals, Registrations, and Patient Consents}

This study was performed in accordance with the Declaration of Helsinki. This study and the FI study are approved by the New England Institutional Review Board, and online consent is obtained from each participant at enrollment.

\section{Data Availability}

Data used in the preparation of this article that could be entirely deidentified are available on Fox Den at foxden. michaeljfox.org. Free-text data that could contain identifying information is not available for public sharing to protect participant privacy.

\section{Results}

One hundred nine instances of figurative language were identified in responses across 86 (4.08\%) participants. Medical terminology was used to describe experiences during off periods by 168 ( $8.06 \%)$ participants, of whom 4 also used figurative language. The remaining participants used literal language.

Among the 86 participants who used figurative language to describe their experience during off periods, the mean (SD) age was 65.26 (7.81) years and mean disease duration was 7.69 (SD 5.07) years. $98.8 \%$ identified as White or Caucasian. Twentynine (33.7\%) had at least 16 years of education; 25 (29\%) had completed a master's degree. A greater proportion of those using figurative language were women (55 [64.0\%] female vs 31 [36.05\%] male, $p=0.002)$. In addition, compared with those who used figurative language, those who did not had a shorter disease duration (mean [SD] 6.07 [5.06] years, $p=$ 0.004 ) but were not significantly different in age (mean [SD] 66.62 [8.57] years, $p=0.147$ ) or educational attainment (proportion with at least 16 years of education was not significantly higher in those using figurative language vs those who did not; $p=0.285$ ).

A variety of figurative devices were used including similes, metaphors, and personification. Themes or categories most commonly represented (table 2) included materials with specific qualities (such as mud or Jell-O) and effects of chemicals (feeling drunk or high). In 14 (12.84\%) instances, a specific theme was not represented per se, but the response fell into a category of a group of miscellaneous objects.

\section{Symptoms Represented by Figurative Language Phrases According to Movement Disorders Neurologists}

When the movement disorders neurologists were asked to interpret the figurative language phrases by indicating which symptoms they felt were represented in them, 1 or 2 symptoms were chosen by each neurologist for most phrases. Examples of phrases and the symptoms selected are shown in table 3 . For 19 phrases, at least 1 neurologist was not able to pick any symptom (table 4 ).

As for the symptoms determined by the neurologists to be most likely represented by each figurative language phrase (table 4), motor symptoms were most commonly selected: slowness was selected by at least 1 neurologist for 29 (26.6\%) 
Table 1 List of Symptoms That the Reviewing Neurologists Used to Specify Which Symptom They Thought Each Figurative Language Phrase Represented

\begin{tabular}{|c|c|}
\hline Category & Symptom \\
\hline \multirow[t]{5}{*}{ Motor-gait/balance/truncal } & Imbalance \\
\hline & Freezing of gait \\
\hline & Retropulsion \\
\hline & Shuffling gait or festination \\
\hline & Flexed/stooped posture \\
\hline \multirow[t]{8}{*}{ Motor-other } & Tremor \\
\hline & Slowness \\
\hline & Stiffness \\
\hline & Dystonia \\
\hline & Dyskinesia \\
\hline & Motor weakness \\
\hline & Motor fluctuation \\
\hline & Freezing of other body parts \\
\hline \multirow[t]{3}{*}{ Bulbar/speech } & Hypophonia \\
\hline & Dysarthria \\
\hline & Trouble swallowing \\
\hline \multirow[t]{2}{*}{ Sensory } & Restlessness/akathisia \\
\hline & Dysesthesia/paresthesia \\
\hline \multirow[t]{5}{*}{ Cognitive } & Concentration \\
\hline & Memory difficulty \\
\hline & Inattentiveness \\
\hline & Bradyphrenia \\
\hline & Cognitive impairment \\
\hline \multirow[t]{4}{*}{ Psychiatric } & Depression \\
\hline & Anxiety/panic \\
\hline & Dissociation \\
\hline & Apathy \\
\hline \multirow[t]{2}{*}{ Fatigue/malaise } & Fatigue \\
\hline & Malaise \\
\hline \multirow[t]{2}{*}{ Autonomic/gastrointestinal } & Dizzy/lightheaded \\
\hline & Nausea \\
\hline
\end{tabular}

Symptoms in bold are those added during review.

phrases, stiffness for 29 (26.6\%) phrases, and tremor for 15 (13.8\%) phrases. Among nonmotor symptoms selected, akathisia/restless $(12[11.0 \%])$ and concentration problems (12 [11.0\%]) were most common.

\section{Agreement Among Movement Disorders Neurologists on the Most Likely Symptom Represented by Figurative Language Phrases}

All 3 neurologists chose the same symptom in 42 (38.5\%) instances, with stiffness being most commonly agreed on (11 phrases), followed by imbalance ( 7 phrases) and slowness (6 phrases). Two of 3 neurologists chose the same symptom for $44(40.4 \%)$ phrases. Inter-rater agreement for $2 / 3$ or $3 / 3$ neurologists for a given category was high for all categories except 19 phrases in which at least 1 neurologist felt unable to pick a given symptom ("I really don't know"; table 4). In 3 instances, all 3 neurologists chose the "I really don't know" option.

Nonmotor symptoms were selected as most likely represented by a given phrase by all 3 neurologists in 27 cases, whereas a motor symptom was selected in 51 cases (table 4). The proportion of phrases with complete agreement between neurologists as to the specific symptom represented was significantly lower in instances where all neurologists selected a nonmotor vs a motor symptom (10 [9.2\%] vs $32[29.4 \%], p=0.0002)$. Proportions of phrases selected as representing a given category, and significant differences in these proportions between categories, are shown in table 5.

\section{Discussion}

Off periods, or the reemergence of motor and nonmotor symptoms as the effect of dopaminergic therapy wears off, are common in PD and have a significant negative impact on QOL. ${ }^{11}$ They are often treatable with medication adjustments, adjunctive medications, or surgical interventions. ${ }^{14}$ Thus, their detection is critical. Indeed, querying patients for medication-related complications is part of the standard of care in PD. ${ }^{15}$ Although questionnaires may be useful to screen for off symptoms, ${ }^{16}$ they do not always capture what bothers patients most. ${ }^{10}$ Including openended questions during patient encounters is an important part of patient care in general, ${ }^{17}$ and may be particularly useful for complex phenomena that have a broad spectrum of manifestations, as in the case of PD off periods. However, patients and caregivers may not be able to clearly articulate the meaning of wearing off, ${ }^{18}$ and other barriers to communication about off periods are not well understood. Understanding these barriers is important toward educating physicians that care for patients with PD to help them detect this important PD manifestation. To improve the understanding of how patients experience off periods and communicate about them, we undertook an in-depth analysis of how patients describe off periods.

Our results illustrate the rich language individuals with PD use to describe off periods and their creative uses of figurative language to explain their symptoms. However, the findings also highlight the complexity that may exist in 
Table 2 Figurative Language Theme Descriptions, Categories, and Examples Used by Individuals With Parkinson Disease to Describe Off Periods

\begin{tabular}{|c|c|c|c|}
\hline Theme & Description & $\begin{array}{l}\mathrm{N}(\%) \text { of phrases categorized into } \\
\text { specified theme }\end{array}$ & $\begin{array}{l}\text { Examples of words used for each } \\
\text { theme }\end{array}$ \\
\hline $\begin{array}{l}\text { Viscous and textured } \\
\text { materials }\end{array}$ & $\begin{array}{l}\text { Any thick or textured substances/ } \\
\text { materials }\end{array}$ & $20(18.4)$ & $\begin{array}{l}\text { Mud, quicksand, Jell-O, pudding, glue, } \\
\text { cement, rubbery, gummy joints, fuzzy }\end{array}$ \\
\hline $\begin{array}{l}\text { Chemical and physiologic } \\
\text { reactions }\end{array}$ & $\begin{array}{l}\text { Intoxication, chemical influences, and } \\
\text { physiologic changes or responses }\end{array}$ & $19(17.4)$ & $\begin{array}{l}\text { Feel high or drunk, like low blood sugar, } \\
\text { like l've had caffeine, feel like l've had } \\
\text { too much to drink, adrenaline rush }\end{array}$ \\
\hline Miscellaneous objects/animal & $\begin{array}{l}\text { Miscellaneous objects used to describe } \\
\text { experience }\end{array}$ & $14(12.8)$ & $\begin{array}{l}\text { Jumping beans, rod, dishrag, fish out of } \\
\text { water, ants under skin }\end{array}$ \\
\hline Confinement & $\begin{array}{l}\text { Being enclosed in or covered by } \\
\text { external object or space }\end{array}$ & $13(11.9)$ & $\begin{array}{l}\text { Armor, cement suit, heavy blanket, } \\
\text { caged animal, encased in cement, } \\
\text { trapped inside body, wrapped in } \\
\text { plastic, straight jacket, sliding down } \\
\text { dark tunnel }\end{array}$ \\
\hline Dissociation or disconnect & $\begin{array}{l}\text { Any disconnect within the body or } \\
\text { between the body and external } \\
\text { surrounding }\end{array}$ & $12(11.0)$ & $\begin{array}{l}\text { Jumping out of skin, stupor, outside my } \\
\text { body looking at myself, detached from } \\
\text { surroundings, catatonic }\end{array}$ \\
\hline Fictional character & $\begin{array}{l}\text { Characterization of a symptom or } \\
\text { phenomena }\end{array}$ & $10(9.2)$ & $\begin{array}{l}\text { Quazimodo, zombie, Mr. Parkinson, } \\
\text { Energizer Bunny, Tin Man }\end{array}$ \\
\hline Extreme experience & $\begin{array}{l}\text { Specific scenarios detailing an } \\
\text { emotionally salient circumstances/ } \\
\text { action }\end{array}$ & $10(9.2)$ & $\begin{array}{l}\text { Rock concert, walking on a tightrope, } \\
\text { airplane crash, car accident, long foot } \\
\text { race, on a rollercoaster, on a cruise ship }\end{array}$ \\
\hline Mechanical & $\begin{array}{l}\text { Objects powered by mechanics or } \\
\text { mechanical part/feature/tool }\end{array}$ & $8(7.3)$ & $\begin{array}{l}\text { Electrical, wired, wheels, clock, } \\
\text { autogiro }\end{array}$ \\
\hline Weather/geological event & $\begin{array}{l}\text { Weather, geological event, } \\
\text { atmospheric conditions }\end{array}$ & $4(3.7)$ & Internal earthquake, in a fog/haze \\
\hline Assault/death & Being physically assaulted or dying & $3(2.8)$ & $\begin{array}{l}\text { Someone choking me, brain is dying, } \\
\text { body under attack }\end{array}$ \\
\hline Water & Referencing water & $3(2.8)$ & $\begin{array}{l}\text { Feels like walking underwater, wave } \\
\text { washing over me }\end{array}$ \\
\hline
\end{tabular}

patient-physician communication about off periods: when reviewed by 3 movement disorders experts, the meaning of the figurative language phrases was agreed on in only approximately $40 \%$ of cases. Agreement was less likely for phrases that were interpreted as representing nonmotor symptoms.

The themes that emerged in the figurative language phrases represented a range of textures, objects, experiences, or images. Patients described a sense of navigating through, or being encased in, various materials such as mud, rubber, glue, and cement. The references to entrapment recall descriptions from patients with amyotrophic lateral sclerosis. ${ }^{6}$ Such phrases were often interpreted by the neurologists as representing motor symptoms such as stiffness and slowness of movement. Another common theme was a sense of being under the influence of exogeneous chemicals/ intoxicated. The latter phrases were deemed to be referring to nonmotor symptoms by the neurologists. Figurative language may particularly be useful to describe complex, abstract, and/or emotionally laden experiences that are hard to explain with literal language, ${ }^{1-4}$ and at the "interface of physical and psychological symptoms." 19
Indeed, many of the figurative language phrases used by participants to describe their off periods convey experiences of great difficulty and discomfort.

Movement disorders neurologists that reviewed the figurative language phrases determined that the phrases most often represented motor symptoms, including stiffness, slowness of movement, and tremor. Tremor ${ }^{20}$ and bradykinesia ${ }^{12}$ are the most commonly reported off symptoms overall, and it is not surprising that these were often selected. However, a variety of nonmotor symptoms were also felt to be represented. This is consistent with an expanding literature on the broad spectrum of both motor and nonmotor symptoms seen in $\mathrm{PD}^{20-22}$

As mentioned, all 3 neurologists agreed on the symptom most likely represented by the figurative language phrase in only $38.5 \%$ of instances. Agreement was more likely for motor symptoms; when a figurative language phrase was interpreted as representing a nonmotor symptom, agreement for which specific symptom was represented was low. This lack of agreement on over half of phrases may reflect a combination of factors, including the heterogeneity intrinsic 
Table 3 Examples of Figurative Language Phrases Written by Patients and Symptoms That Each of 3 Neurologists Determined Were Most Likely Represented in Each Phrase

\begin{tabular}{lll}
\hline $\begin{array}{l}\text { Verbatim phrase (figurative language in } \\
\text { bold) }\end{array}$ & $\begin{array}{l}\text { Most likely symptom represented (no. of } \\
\text { neurologists) }\end{array}$ & $\begin{array}{l}\text { Other possible symptoms being } \\
\text { represented (no. of neurologists) }\end{array}$ \\
\hline $\begin{array}{l}\text { I become sluggish and feel that my limbs } \\
\text { resist making any movements like being in a } \\
\text { straight jacket. }\end{array}$ & Stiffness (3) &
\end{tabular}

\section{My body is fatigued, like it's hit a wall and Fatigue (3)}

crashed.

It feels like I have no medication in me. It is as if the battery in the energizer Bunny just quits:) My body slows down and gets stiffer;

sometimes it is difficult to breathe and my left

hand tremor returns...

Feel as if I can implode-I hunch over and pull my head into my shoulders. I feel cold and shake.

Internal tremors like an internal earthquake followed by a switch being turned and my tremors come in my left side predominantly.

Ohyes, the power from one time to another is the power ability to exert missing. Sometimes

I have deliberately tried to be angry Or just

stop my foot or smash my hand and I cannot.

It makes me feel paralyzed or trapped inside my body.

Tightness in jaws and feel like someone is chocking me. My nose runs without stopping and I must spit out saliva constantly, especially when I first get up. Though I desperately need the meds, recently, I have been unable to swallow them.

Nervous, edgy, muscle tightness, like I am going to crawl out of my skin

I feel like my body is under attack during off period, the calm feeling that I have is turning into shaking and stiffness.

I feel like a clock that has run completely down and I move all over. I just feel awful.

I think of my off periods as being like a heavy coat or blanket dropping over me, covering my whole body with exhaustion, instability, fogginess, and an overall sick feeling. When it hits, it is difficult for me to do anything other than lying down and waiting for it to pass.

When I am off, my feet feel like they are wrapped in heavy plastic; they are tingly and numb.

I also get sad and discouraged. Sometimes | feel it coming on...like I am sliding down a dark tunnel.

I can't pick up my feet. Legs feel rubbery.

It's not that I can't think straight or carry on a conversation, but the "wheels" seem to turn very slowly and I get quiet. I feel vulnerable and depleted, and sometimes anxious. Motor weakness (1)

Slowness (1)

Fatigue (1)

Flexed/stooped posture (1)

Dystonia (1)

I really don't know (1)

Tremor (3)
Motor weakness (2)

Freezing of gait (1)
Stiffness (1)

Slowness (2)

Stiffness (1)

Dystonia (1)

Trouble swallowing (1)
Restlessness/akathisia (2) Stiffness (1)

Anxiety/panic (1)

Tremor (1)

Anxiety/panic (1)

Stiffness (1)

I really don't know (1)

Motor weakness (1)

Slowness (1)

Malaise (1)

Slowness (2)

Motor weakness (1)

Malaise (1)

Nausea (1)

Fatigue (1)

Stiffness (1)

Like being in jail in my Own body. 
Table 3 Examples of Figurative Language Phrases Written by Patients and Symptoms That Each of 3 Neurologists Determined Were Most Likely Represented in Each Phrase (continued)

\begin{tabular}{|c|c|c|}
\hline $\begin{array}{l}\text { Verbatim phrase (figurative language in } \\
\text { bold) }\end{array}$ & $\begin{array}{l}\text { Most likely symptom represented (no. of } \\
\text { neurologists) }\end{array}$ & $\begin{array}{l}\text { Other possible symptoms being } \\
\text { represented (no. of neurologists) }\end{array}$ \\
\hline $\begin{array}{l}\text { It's like flying in a plane } 30,000 \mathrm{ft} \text {. in the air, } \\
\text { and all of a sudden, it begins its descent. I } \\
\text { feel dejected, rejected, and that my life is not } \\
\text { worth living. }\end{array}$ & $\begin{array}{l}\text { Depression (1) } \\
\text { Fluctuation (1) } \\
\text { Anxiety/panic (1) }\end{array}$ & \\
\hline
\end{tabular}

Number in parenthesis indicates the number of neurologists that designated a specific symptom (maximum 3).

to $\mathrm{PD},{ }^{23}$ the broad range of ways in which patients experience complex PD manifestations and communicate about them, ${ }^{24,25}$ and the inherently subjective nature of interpreting figurative language. ${ }^{26}$ These and other factors may lead to misunderstandings in communication about off periods and, in turn, their suboptimal detection ${ }^{12}$ and treatment. These results highlight the importance of active listening and clarifying information during provider-patient communication and add an additional facet to the idea of "shared understanding.", 9 Much research has focused on how to improve patient understanding of what physicians are communicating to them. In that context, the use of

Table 4 Specific Symptoms and Categories of Symptoms Indicated by Neurologist as Most Likely to Be Represented by Figurative Language Phrase and Agreement Among Neurologists

\begin{tabular}{|c|c|c|c|c|c|c|c|}
\hline Symptom & $\begin{array}{l}\text { Selected by } \geq 1 \\
\text { neurologist }^{\mathrm{a}}\end{array}$ & Category & $\begin{array}{l}\text { Frequency (no. of } \\
\text { phrases) }\end{array}$ & $\begin{array}{l}\text { Only } 1 \\
\text { neurologist }^{\mathrm{b}}\end{array}$ & $\begin{array}{l}2 / 3 \\
\text { neurologists }^{b}\end{array}$ & $\begin{array}{l}3 / 3 \\
\text { neurologists }^{b}\end{array}$ & Kappa \\
\hline Imbalance & 9 & \multirow{5}{*}{$\begin{array}{l}\text { Motor-gait/balance/ } \\
\text { truncal }\end{array}$} & \multirow[t]{5}{*}{17} & \multirow[t]{5}{*}{$7(41 \%)$} & \multirow[t]{5}{*}{$1(6 \%)$} & \multirow[t]{5}{*}{$9(53 \%)$} & \multirow[t]{5}{*}{$0.7503^{c}$} \\
\hline Freezing of gait & 5 & & & & & & \\
\hline Retropulsion & 0 & & & & & & \\
\hline Shuffling gait or festination & 1 & & & & & & \\
\hline Flexed/stooped posture & 2 & & & & & & \\
\hline Tremor & 16 & \multirow[t]{8}{*}{ Motor-other } & \multirow[t]{8}{*}{70} & \multirow[t]{8}{*}{$10(14 \%)$} & \multirow[t]{8}{*}{$18(26 \%)$} & \multirow[t]{8}{*}{$42(60 \%)$} & \multirow[t]{8}{*}{$0.6566^{c}$} \\
\hline Slowness & 29 & & & & & & \\
\hline Stiffness & 29 & & & & & & \\
\hline Dystonia & 2 & & & & & & \\
\hline Dyskinesia & 1 & & & & & & \\
\hline Motor weakness & 15 & & & & & & \\
\hline Motor fluctuation & 7 & & & & & & \\
\hline Freezing of other body parts & 0 & & & & & & \\
\hline Hypophonia & 1 & \multirow[t]{3}{*}{ Bulbar/speech } & \multirow[t]{3}{*}{3} & \multirow[t]{3}{*}{$1(50 \%)$} & \multirow[t]{3}{*}{$1(25 \%)$} & \multirow[t]{3}{*}{$1(25 \%)$} & \multirow[t]{3}{*}{$0.6604^{c}$} \\
\hline Dysarthria & 1 & & & & & & \\
\hline Trouble swallowing & 2 & & & & & & \\
\hline Restlessness/akathisia & 12 & \multirow[t]{2}{*}{ Sensory } & \multirow[t]{2}{*}{16} & \multirow[t]{2}{*}{$9(56 \%)$} & \multirow[t]{2}{*}{$4(25 \%)$} & \multirow[t]{2}{*}{$3(19 \%)$} & \multirow[t]{2}{*}{$0.4568^{c}$} \\
\hline Dysesthesia/paresthesia & 4 & & & & & & \\
\hline Concentration & 12 & \multirow[t]{5}{*}{ Cognitive } & \multirow[t]{5}{*}{17} & \multirow[t]{5}{*}{$4(33 \%)$} & \multirow[t]{5}{*}{$5(42 \%)$} & \multirow[t]{5}{*}{$3(25 \%)$} & $0.5791^{c}$ \\
\hline Memory difficulty & 0 & & & & & & \\
\hline Inattentiveness & 0 & & & & & & \\
\hline Bradyphrenia & 1 & & & & & & \\
\hline Cognitive impairment & 4 & & & & & & \\
\hline Depression & 3 & Psychiatric & 13 & $5(38.5 \%)$ & $3(23 \%)$ & $5(38.5 \%)$ & $0.6657^{c}$ \\
\hline Anxiety/panic & 8 & & & & & & \\
\hline Dissociation & 4 & & & & & & \\
\hline Apathy & 0 & & & & & & \\
\hline Fatigue & 7 & Fatigue/malaise & 10 & $7(70 \%)$ & $1(10 \%)$ & $2(20 \%)$ & $0.4410^{c}$ \\
\hline Malaise & 4 & & & & & & \\
\hline Dizzy/lightheaded & 1 & Autonomic/Gl & 1 & $1(100 \%)$ & 0 & 0 & -0.0031 \\
\hline Nausea & 0 & & & & & & \\
\hline I really don't know & 19 & I really don't know & 19 & $16(84 \%)$ & $3(16 \%)$ & 0 & 0.0741 \\
\hline
\end{tabular}


Table 5 Proportion of Phrases for Which Agreement Was Present Among All 3 Neurologists as to the Most Likely Category of Symptoms Being Represented

\begin{tabular}{|c|c|c|c|c|c|c|c|c|c|}
\hline $\begin{array}{l}\text { Symptom } \\
\text { category }\end{array}$ & $\begin{array}{l}\text { No. of } \\
\text { phrases } \\
\text { designated } \\
\text { by } \geq 1 \\
\text { neurologist } \\
\text { as } \\
\text { representing } \\
\text { a symptom } \\
\text { belonging to } \\
\text { specified } \\
\text { category }\end{array}$ & $\begin{array}{l}\text { Proportion } \\
\text { achieving } \\
\text { agreement } \\
\text { ( } 3 / 3 \\
\text { neurologists) }\end{array}$ & Motor_other & Motor_gait_trunk & Bulbar_speech & Sensory & Cognitive & Psychiatric & Fatigue_malaise \\
\hline Motor_other & 70 & $60.0 \%$ & & & & & & & \\
\hline Motor_gait_trunk & 17 & $52.9 \%$ & 0.596 & & & & & & \\
\hline Bulbar_speech & 3 & $33.3 \%$ & 0.358 & 0.531 & & & & & \\
\hline Sensory & 16 & $18.8 \%$ & $0.003^{a}$ & $0.041^{a}$ & 0.570 & & & & \\
\hline Cognitive & 12 & $25.0 \%$ & $0.024^{a}$ & 0.132 & 0.770 & 0.690 & & & \\
\hline Psychiatric & 13 & $38.5 \%$ & 0.150 & 0.431 & 0.869 & 0.238 & 0.471 & & \\
\hline Fatigue_malaise & 10 & $20.0 \%$ & $0.017^{a}$ & 0.093 & 0.631 & 0.937 & 0.781 & 0.340 & \\
\hline Autonomic_GI & 1 & 0 & 0.226 & 0.303 & 0.505 & 0.633 & 0.569 & 0.439 & 0.621 \\
\hline Don't know & 19 & 0 & $<0.001^{a}$ & $<0.001$ & $0.010^{a}$ & $0.048^{a}$ & $0.022^{a}$ & $0.033^{a}$ & $0.043^{a}$ \\
\hline
\end{tabular}

figurative language by physicians was reported by cancer patients to improve their understanding of health problems and increase their satisfaction. ${ }^{27}$ However, the impact of figurative language on the communication of patients with their providers is less well studied. One study in cancer patients indicated that providers may not recognize or respond to patients' use of figurative expression. ${ }^{28}$ Our results highlight a simple yet important aspect of patient-physician communication: that physicians should not assume complete or accurate comprehension of what a patient means when they describe their experiences using figurative language that could be interpreted in different ways. Rather, relating to the patient what meaning was taken, and simply asking the patient what they meant in such circumstances, allows the opportunity for further clarification and exploration. These and other active listening techniques ${ }^{29,30}$ foster a patient-centered approach that could help enhance patientphysician communication, patient satisfaction, and ultimately may improve patient outcomes. ${ }^{17,31}$

The question that asked participants about their experience during off periods was open-ended and allowed for free-text responses. In this written format, most participants used literal language to describe their experience. However, even in this research setting where figurative language was not specifically elicited, $4 \%$ of responses used some form of it. Figurative language may be used more often during verbal communication (such as would occur in the clinic) as compared to written communication. ${ }^{32}$ Thus, healthcare providers will encounter the use of figurative language to describe off periods, whether in clinic or in written text by patients to their healthcare team such as in patient messages sent in the electronic medical record. Awareness of the high frequency of ambiguity in the meaning of figurative language in this context leading to caution against assuming what a patient means without clarifying has the potential to improve communication between healthcare providers and patients with PD.

In our study, a larger proportion of those using figurative language were women. Sex differences in frequency and type of metaphor used has been reported in other patient populations such as those with depression. ${ }^{33}$ Additional work to better understand sex or other demographic differences in the type of language used in description of PD experiences also has the potential to enhance patient-physician communication.

The design of this study did not allow for us to ask participants what they meant by the figurative language phrase they used. This is a limitation of this study, and future work will incorporate this critical aspect to better understand the use of figurative language in PD. Other limitations include the relatively high education and low diversity of our sample; this is particularly relevant, given cultural influences on the use of figurative language. ${ }^{34}$ Therefore, our results may not be generalizable to the broader PD population. 
Individuals with $\mathrm{PD}$ use a wide range of figurative language to describe their experience with off periods. An awareness of this, and the potential for even an experienced physician to not grasp the full meaning intended to be relayed by the patient, is an important step toward improving patientphysician communication.

\section{Acknowledgment}

This work occurred as part of the Michael J. Fox Foundation's Parkinson's Disease Education Consortium 2018 (PDEC 2018) project. The PDEC is sponsored by the following industry partners: ACADIA Pharmaceuticals, Adamas Pharmaceuticals, Intec Pharma, Lundbeck Inc., and Sunovion Pharmaceuticals. The Fox Insight study is funded by the Michael J. Fox Foundation for Parkinson's Research. We would like to thank the Parkinson's community for participating in this study to make this research possible.

\section{Study Funding}

Supported by the Michael J. Fox Foundation for Parkinson's Disease Research.

\section{Disclosure}

L.M. Chahine receives research support from the Michael J. Fox Foundation, including for the PDEC study, receives research support from the UPMC Competitive Medical Research Fund and University of Pittsburgh, is study site investigator for a study sponsored by Biogen, and receives royalties from Wolters Kluwer (for book authorship). B. Edison receives research support from the Michael J. Fox Foundation. M. Daescher was an of MJFF employee at the time some of this work was done. B. Siddiqui is an MJFF employee. C. Kopil is an MJFF employee. C. Marras receives

\section{TAKE-HOME POINTS}

$\rightarrow$ Figurative language may particularly be useful to describe complex, abstract, and/or emotionally laden experiences that are hard to explain with literal language; individuals with PD use figurative language to describe their experiences with off periods.

$\rightarrow$ Neurologists agreed on what symptoms the figurative language phrases were referring to in only a minority of instances.

$\rightarrow$ To optimize physician-patient communication around off periods, it is important for neurologists who care for patients with PD to be the alert for possible use of figurative language by patients, and to ensure, through active listening and clarifying questions that the meaning intended to be relayed by the patient is understood. research support from the Michael J. Fox Foundation, the Canadian Institutes of Health Research, the Parkinson's Foundation (US) and the International Parkinson and Movement Disorder Society, and is a site investigator for a research study supported by Theravance Biopharma. S. Mantri receives research support from the Michael J. Fox Foundation (MJFF), the Parkinson's Foundation (PF), and Cerevel Therapeutics, was a paid consultant to MJFF, is a study site investigator for a study sponsored by Neuraly Rho, is a study site subinvestigator for a study sponsored by Biogen, and is contracted with Deep Brain Innovations, LLC. Full disclosure form information provided by the authors is available with the full text of this article at Neurology.org/cp.

\section{Publication History}

Received by Neurology: Clinical Practice July 18, 2020. Accepted in final form January 6, 2021.

\section{Appendix Authors}

\begin{tabular}{|c|c|c|}
\hline Name & Location & Contribution \\
\hline $\begin{array}{l}\text { Lana M. } \\
\text { Chahine, MD, } \\
\text { MS }\end{array}$ & $\begin{array}{l}\text { Department of Neurology, } \\
\text { University of Pittsburgh, PA }\end{array}$ & $\begin{array}{l}\text { Study design, acquisition, } \\
\text { analysis, interpretation of } \\
\text { data, and drafting the work } \\
\text { final approval of the } \\
\text { version to be published }\end{array}$ \\
\hline $\begin{array}{l}\text { Briana Edison, } \\
\text { MPH }\end{array}$ & $\begin{array}{l}\text { Department of Neurology, } \\
\text { University of Pittsburgh, PA }\end{array}$ & $\begin{array}{l}\text { Study design, acquisition, } \\
\text { interpretation of data, and } \\
\text { review and revision of } \\
\text { manuscript }\end{array}$ \\
\hline $\begin{array}{l}\text { Margaret } \\
\text { Daeschler, MA }\end{array}$ & $\begin{array}{l}\text { Georgetown University, } \\
\text { Washington, DC }\end{array}$ & $\begin{array}{l}\text { Study design and review } \\
\text { and revision of manuscript }\end{array}$ \\
\hline $\begin{array}{l}\text { Bernadette } \\
\text { Siddiqi, MA }\end{array}$ & $\begin{array}{l}\text { The Michael J. Fox } \\
\text { Foundation for Parkinson's } \\
\text { Research, New York }\end{array}$ & $\begin{array}{l}\text { Review and revision of } \\
\text { manuscript }\end{array}$ \\
\hline $\begin{array}{l}\text { Catherine } \\
\text { Kopil, PhD }\end{array}$ & $\begin{array}{l}\text { The Michael J. Fox } \\
\text { Foundation for Parkinson's } \\
\text { Research, New York }\end{array}$ & $\begin{array}{l}\text { Study design and review } \\
\text { and revision of manuscript }\end{array}$ \\
\hline $\begin{array}{l}\text { Connie Marras, } \\
\text { MD, PhD }\end{array}$ & $\begin{array}{l}\text { The Edmond J. Safra } \\
\text { Program in Parkinson's } \\
\text { disease, Toronto Western } \\
\text { Hospital, University of } \\
\text { Toronto, Ontario, Canada }\end{array}$ & $\begin{array}{l}\text { Study design, acquisition, } \\
\text { interpretation of data, and } \\
\text { review and revision of } \\
\text { manuscript }\end{array}$ \\
\hline $\begin{array}{l}\text { Sneha Mantri, } \\
\text { MD, MS }\end{array}$ & $\begin{array}{l}\text { Department of Neurology, } \\
\text { Duke University, Durham, } \\
\text { NC }\end{array}$ & $\begin{array}{l}\text { Study design, acquisition, } \\
\text { analysis, interpretation of } \\
\text { data, and drafting the work } \\
\text { final approval of the } \\
\text { version to be published }\end{array}$ \\
\hline
\end{tabular}

\section{References}

1. Cameron L, Stelma JH. Metaphor clusters in discourse. J Appl Linguistics 2004;1: 107-136.

2. Semino E. Metaphor in Discourse. Cambridge University Press; 2008.

3. Kövecses Z. Metaphor and Emotion: Language, Culture, and Body in Human Feeling. Cambridge University Press; 2000.

4. Periyakoil VS. Using metaphors in medicine. J Palliat Med 2008;11:842-844.

5. Sontag S. Illness as Metaphor. Farrar, Straus and Giroux; 1978.

6. Locock L, Mazanderani F, Powell J. Metaphoric language and the articulation of emotions by people affected by motor neurone disease. Chronic Illn 2012;8:201-213.

7. Zimmermann M. Alzheimer's disease metaphors as mirror and lens to the stigma of dementia. Lit Med 2017;35:71-97.

8. Charon R. The patient-physician relationship. narrative medicine: a model for empathy, reflection, profession, and trust. JAMA 2001;286:1897-1902.

9. Vaccarella M. Narrative epileptology. Lancet 2011;377:460-461. 
10. Chahine LM, Edison B, Daeschler M, et al. The most bothersome aspects of off periods reported by individuals with Parkinson's disease. Mov Disord Clin Pract 2020;7:284-292.

11. Storch A, Schneider CB, Wolz M, et al. Nonmotor fluctuations in Parkinson disease: severity and correlation with motor complications. Neurology 2013;80: 800-809.

12. Martinez-Martin P, Tolosa E, Hernandez B, Badia X. The patient card questionnaire to identify wearing-off in Parkinson disease. Clin Neuropharmacol 2007;30:266-275.

13. Smolensky L, Amondikar N, Crawford K, et al. Fox insight collects online, longitudinal patient-reported outcomes and genetic data on Parkinson's disease. Sci Data 2020;7:67.

14. Fox SH, Katzenschlager R, Lim SY, et al. International Parkinson and movement disorder society evidence-based medicine review: update on treatments for the motor symptoms of Parkinson's disease. Mov Disord 2018;33:1248-1266.

15. Cheng EM, Tonn S, Swain-Eng R, Factor SA, Weiner WJ, Bever CT Jr; American Academy of Neurology Parkinson Disease Measure Development Panel. Quality improvement in neurology: AAN Parkinson disease quality measures: report of the quality measurement and reporting subcommittee of the American Academy of Neurology. Neurology 2010;75:2021-2027.

16. Antonini A, Martinez-Martin P, Chaudhuri RK, et al. Wearing-off scales in Parkinson's disease: critique and recommendations. Mov Disord 2011;26:2169-2175.

17. Zulman DM, Haverfield MC, Shaw JG, et al. Practices to foster physician presence and connection with patients in the clinical encounter. JAMA 2020;323:70-81.

18. Matthews H, Stamford J, Saha R, Martin A, Off-Park survey steering group. Exploring issues around wearing-off and quality of life: the OFF-PARK survey of people with Parkinson's disease and their care partners. J Parkinsons Dis 2015;5: 533-539.

19. Skelton JR, Wearn AM, Hobbs FD. A concordance-based study of metaphoric expressions used by general practitioners and patients in consultation. $\mathrm{Br} \mathrm{J}$ Gen Pract 2002;52:114-118.

20. Stacy M, Bowron A, Guttman M, et al. Identification of motor and nonmotor wearingoff in Parkinson's disease: comparison of a patient questionnaire versus a clinician assessment. Mov Disord 2005;20:726-733.
21. Raudino F. Non motor off in Parkinson's disease. Acta Neurol Scand 2001;104: 312-315.

22. Witjas T, Kaphan E, Azulay JP, et al. Nonmotor fluctuations in Parkinson's disease: frequent and disabling. Neurology 2002;59:408-413.

23. Greenland JC, Williams-Gray CH, Barker RA. The clinical heterogeneity of Parkinson's disease and its therapeutic implications. Eur J Neurosci 2019;49: 328-338.

24. Armstrong MJ, Rastgardani T, Gagliardi AR, Marras C. Barriers and facilitators of communication about off periods in Parkinson's disease: qualitative analysis of patient, carepartner, and physician interviews. PLoS One 2019;14:e0215384.

25. Rastgardani T, Armstrong MJ, Gagliardi AR, Grabovsky A, Marras C. Communication about OFF periods in Parkinson's disease: a survey of physicians, patients, and carepartners. Front Neurol 2019;10:892.

26. Thibodeau PH, Sikos L, Durgin FH. Are subjective ratings of metaphors a red herring? The big two dimensions of metaphoric sentences. Behav Res Methods 2018;50:759-772.

27. Casarett D, Pickard A, Fishman JM, et al. Can metaphors and analogies improve communication with seriously ill patients? J Palliat Med 2010;13:255-260.

28. Lanceley A, Clark JM. Cancer in other words? The role of metaphor in emotion disclosure in cancer patients. Br J Psychother 2013;29:182-201.

29. Lang F, Floyd MR, Beine KL. Clues to patients' explanations and concerns about their illnesses. A call for active listening. Arch Fam Med 2000;9:222-227.

30. Hashim MJ. Patient-centered communication: basic skills. Am Fam Physician 2017; 95:29-34.

31. Stewart MA. Effective physician-patient communication and health outcomes: a review. CMAJ 1995;152:1423-1433.

32. Fussel SR, Mallie M. Figurative language in emotional communication. In: Fussel SR, Kreuz RJ, eds. Social and Cognitive Approaches to Interpersonal Communication. Lawrence Erlbaum Associates; 1998:1-31.

33. Charteris-Black J. Shattering the bell jar: metaphor, gender, and depression. Metaphor Symb 2012;27:199-216.

34. Meili I, Maercker A. Cultural perspectives on positive responses to extreme adversity: a playing field for metaphors. Transcult Psychiatry 2019;56:1056-1075. 


\title{
Neurology ${ }^{\circ}$ Clinical Practice
}

\author{
Use of Figurative Language by People With Parkinson Disease to Describe "Off" \\ Periods: Clear as Mud \\ Lana M. Chahine, Briana Edison, Margaret Daeschler, et al. \\ Neurol Clin Pract 2021;11;e462-e471 Published Online before print March 9, 2021 \\ DOI 10.1212/CPJ.0000000000001059
}

This information is current as of March 9, 2021

\begin{abstract}
Updated Information \& Services

References

Subspecialty Collections

Permissions \& Licensing

Reprints

including high resolution figures, can be found at: http://cp.neurology.org/content/11/4/e462.full.html

This article cites 30 articles, 5 of which you can access for free at: http://cp.neurology.org/content/11/4/e462.full.html\#\#ref-list-1

This article, along with others on similar topics, appears in the following collection(s):

All Clinical Neurology

http://cp.neurology.org//cgi/collection/all_clinical_neurology

Parkinson's disease/Parkinsonism

http://cp.neurology.org//cgi/collection/parkinsons_disease_parkinsonis $\mathrm{m}$ its entirety can be found online at:

http://cp.neurology.org/misc/about.xhtml\#permissions

Information about ordering reprints can be found online:

http://cp.neurology.org/misc/addir.xhtml\#reprintsus
\end{abstract}

Information about reproducing this article in parts (figures,tables) or in

Neurol Clin Pract is an official journal of the American Academy of Neurology. Published continuously since 2011, it is now a bimonthly with 6 issues per year. Copyright (C 2021 The Author(s). Published by Wolters Kluwer Health, Inc. on behalf of the American Academy of Neurology.. All rights reserved. Print ISSN: 2163-0402. Online ISSN: 2163-0933.

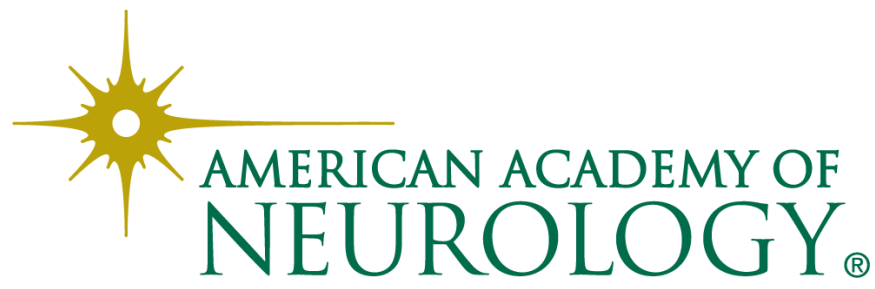

